\title{
The prevalence of bruxism and related factors in patients with multiple sclerosis: a comparative study
}

\section{A prevalência do bruxismo e fatores relacionados em pacientes com esclerose múltipla: um estudo comparativo}

Faruk Ömer Odabas' ${ }^{1}$ Ali Ulvi Uca²

\begin{abstract}
Objective: To determine the prevalence of bruxism and related factors in patients with multiple sclerosis (MS). Methods: Diagnosed with relapsing-remitting MS under the 2010-revised McDonald diagnostic criteria, 182 patients without MS exacerbations during the previous three months were included in the patient group, and 145 healthy individuals made up the control group in the study. Demographic data of the participants in both groups were determined. In the patient and control groups, the diagnosis of definite bruxism was made using the International Classification of Sleep Disorders (Diagnosis and Coding Manual, Second Edition). Results: Bruxism was found in 29.7\% $(n=54)$ of the patients and in $12.4 \%(n=18)$ of the controls, and the difference was statistically significant $(p<0.001)$. Of all patients, the onset of bruxism was found in $70.4 \%(n=38)$ after the diagnosis and in $29.6 \%(n=169)$ prior to the diagnosis of MS. Compared with those without bruxism, the mean age $(p=0.031)$ and the score of the Expanded Disability Status Scale $(p=0.001)$ were also significantly higher among MS patients with bruxism. Between MS patients with and without bruxism, no significant differences were found in terms of sex, marital status, educational status, employment, cigarette smoking, total number of exacerbations, number of exacerbations within the previous year, and drugs used. Conclusions: The frequency of bruxism was found to be higher in the patients with MS than in the controls. Bruxism is associated with age and the Expanded Disability Status Scale score in MS patients.
\end{abstract}

Keywords: Bruxism; multiple sclerosis.

\section{RESUMO}

Objetivo: Neste estudo, pretendeu-se determinar a prevalência de bruxismo e fatores relacionados em pacientes com esclerose múltipla (EM). Métodos: Diagnosticados com EM remitente recidivante sob os critérios de McDonald Diagnostic revisados em 2010,182 pacientes sem ataques de EM durante os últimos três meses foram incluídos no grupo de pacientes, e 145 indivíduos saudáveis constituíram o grupo de controle no estudo. Os dados demográficos dos participantes dos dois grupos foram determinados. Nos grupos de pacientes e controle, o diagnóstico de bruxismo definitivo foi feito usando a Classificação Internacional de Distúrbios do Sono (1) (Manual de Diagnóstico e Codificação Segunda Edição). Resultados: O bruxismo foi detectado em 29,7\% ( $n=54)$ dos pacientes e observado dentro de 12,4\% ( $n=18$ ) dos controles, e a diferença foi estatisticamente significante ( $p<0,001)$. De todos os pacientes, o tempo inicial de bruxismo foi encontrado em 70,4\% ( $n=38$ ) após o diagnóstico e em 29,6\% ( $n=169)$ antes do diagnóstico. Em comparação com aqueles sem bruxismo, os níveis de idade média ( $p=0,031)$ e o escore da Escala de Status de Incapacidade Expandida ( $p=0,001)$ também foram significativamente maiores entre os pacientes com esclerose múltipla com bruxismo. Entre os pacientes com esclerose múltipla com e sem bruxismo, não foi encontrada diferença significativa em termos de sexo, estado civil, status educacional, emprego, tabagismo, número total de ataques, número de ataques no último ano e medicamentos utilizados. Conclusões: A freqüência de bruxismo foi maior em pacientes com esclerose múltipla do que nos controles. O bruxismo está associado à idade e ao escore da Escala de Status de Incapacidade Expandida (EDSS) em pacientes com EM.

Palavras-chave: Bruxismo; Esclerose múltipla.

\footnotetext{
1 University of Health Sciences, Konya Health Application and Research Center, Department of Neurology, Konya,Turkey;

${ }^{2}$ Necmettin Erbakan University, Meram Faculty of Medicine, Department of Neurology, Konya, Turkey.

Faruk Ömer Odabas (iD) https://orcid.org/0000-0001-9136-9388

Correspondence: Faruk Ömer Odabas; Department of Neurology, Konya Health Application and research center, University of Health Sciences, Konya,Turkey ,42090, 0.505.4421093; E-mail: fodabas2002@yahoo.com

Conflict of interest: There is no conflict of interest to declare.

Ethics Committee Approval: Ethics: The work described in this article has been carried out in accordance with the Code of Ethics of the World Medical Association (Declaration of Helsinki) for experiments involving humans; Uniform Requirements for manuscripts submitted to Biomedical journals. Ethics committee approval was received for this study from the ethics committee of University of Selçuk.

Received 25 July 2018; Received in final form 29 November 2018; Accepted 14 December 2018.
} 
Bruxism is a stereotypic movement disorder described as the grinding or gnashing and clenching of teeth ${ }^{1}$, and affects between $8-21 \%$ of the general public ${ }^{2,3}$. The most commonly used criterion is the time during which bruxism takes place, and according to this criterion, bruxism is classified as either diurnal bruxism, occurring during the day, or as nocturnal bruxism, occurring at night. In diurnal bruxism, involuntary contractile activity of the masseter muscle and clenching of the front teeth, and gnashing or grinding are commonly seen signs ${ }^{4}$. While the diurnal type is witnessed in $20 \%$ of the general population, mainly in women, the nocturnal type is encountered in $8-16 \%$ of the population ${ }^{5}$.

Bruxism is a condition affecting children, adults and both sexes, and the mean age of onset ranges between 17 and 20 years in the general public ${ }^{6,7}$. Although idiopathic nocturnal bruxism is frequently observed in the general population, bruxism has been reported in a variety of neurological conditions, such as Huntington's disease, craniocervical dystonia, post-anoxic brain damage, coma, cerebellar syndrome, Rett syndrome and Whipple disease, mental retardation, drugs providing dopamine receptor blockade and the use of selective serotonin re-uptake inhibitors ${ }^{3,8}$.

Although the etiology of bruxism has yet to be fully understood, the formation and pathogenesis of bruxism are considered to be multifactorial. The etiological factors are primarily grouped under two headings as morphological and central ${ }^{8}$.

In the literature, studies investigating the coexistence of MS and bruxism are limited. In the present study, we aimed to investigate the association between multiple sclerosis (MS) and bruxism, and their related factors.

\section{METHODS}

One hundred and eighty-two patients diagnosed with relapsing-remitting MS under the 2010-revised McDonald diagnostic criteria, and without MS exacerbations during the previous three months, were included in the patient group, while 145 healthy individuals made up the control group in the study. The demographic data of all individuals in both groups were determined. In the patient group, the age of onset of MS, treatment modality, existence of additional diseases, total number of exacerbations, and number of exacerbations experienced within the previous year were recorded. All individuals in the patient group were examined neurologically, and their Expanded Disability Status Scale (EDSS) scores were determined. The existence of bruxism was investigated in all participants in both groups by using the International Classification of Sleep Disorders (Diagnosis and Coding Manual, Second Edition) produced by the American Academy of Sleep Medicine and the European Sleep Research Society ${ }^{1}$. In addition, whether bruxism developed before or after the diagnosis of MS was also investigated. The diagnostic criteria used for bruxism were:
1) The daytime or nocturnal grinding or clenching of teeth (noticed by the patients or their spouses).

2) The existence at least one of the following:

a. Abnormal appearance in the teeth

b. Pain/fatigue developing in the jaw muscles

c. Hypertrophy of the masseter muscles.

Patients with a neurological disorder, such as tensiontype headache, or cerebrovascular diseases, endocrine disorders, cardiovascular and pulmonary systemic disorders, those diagnosed with psychiatric diseases, such as bipolar or psychotic disorders, anxiety disorder and depression, those using drugs affecting serotonergic or dopaminergic systems, illegal drug users and those with a history of temporomandibular joint dysfunction and head trauma were excluded from the study.

Approval was obtained from the local ethics board.

\section{Statistical analysis}

All statistical analyses were carried out using the Statistical Package for Social Sciences (SPSS) software for Windows, version 16.0 (SPSS Inc. IL, USA). The prevalence and incidence of bruxism were determined with descriptive statistics. The differences were assessed with the $t$ test and Mann-Whitney U test for continuous variables. Paired categorical variables between the groups were analyzed with the $\chi^{2}$ and Fisher's exact tests. All significance levels were twotailed and set at the level of 0.05 .

\section{RESULTS}

In the general characteristics of all individuals in the patient and control groups, the mean age level was $37.48 \pm 9.75$; and $74.5 \%(n=250)$ of all participants were married, while $17.7 \%(n=58)$ were unmarried, and $5.8 \%(n=19)$ were divorced. In terms of educational status, $48.3 \%(n=158)$, $28.4 \%(n=93)$ and $23.2 \%(n=76)$ of all participants had graduated from primary school, high school and college, respectively; and, given employment status, $32.7 \%(\mathrm{n}=107)$ were employed, while $67.3 \%$ ( $n=220)$ were unemployed.

In the patient group, the mean age was $36.47 \pm 8.82$ $(t=-0.72, p=0.468)$. In terms of sex, $71.4 \%(n=130)$ of the individuals in the patient group and $71.0 \%(\mathrm{n}=103)$ of the controls were women.

The mean age at onset and mean disease duration were $29.9 \pm 8.20$ years (14-55 years) and $6.59 \pm 4.84$ years respectively, and the mean EDSS score of the patients was $1.34 \pm 1.09$. In addition, the total number of MS exacerbations varied between 1-5 in 144 patients (79.1\%), 6-10 exacerbations in 29 (15.9\%) patients and more than 10 exacerbations in $9(4.9 \%)$ patients.

As seen in Table 1, no difference was observed between the patient and control groups in terms of age, sex, marital status, employment status, educational level and cigarette smoking. 
Table 1. Demographic data of the multiple sclerosis patients and controls.

\begin{tabular}{|c|c|c|c|}
\hline Variable & Patients $(n=182)$ & Controls $(n=145)$ & $\mathrm{p}$-value \\
\hline Age & $36.47 \pm 8.82$ & $37.25 \pm 10.66$ & $0.468^{*}$ \\
\hline \multicolumn{4}{|l|}{ Sex } \\
\hline Male & $52(28.6 \%)$ & $42(29.0 \%)$ & $1.000^{+}$ \\
\hline Female & $130(71.4 \%)$ & $103(71.0 \%)$ & \\
\hline \multicolumn{4}{|l|}{ Marital status } \\
\hline Married & $142(78.0 \%)$ & $108(74.5 \%)$ & $0.235^{\ddagger}$ \\
\hline Unmarried & $33(18.1 \%)$ & $25(17.2 \%)$ & \\
\hline Divorced & $7(3.8 \%)$ & $12(8.3 \%)$ & \\
\hline \multicolumn{4}{|l|}{ Employment } \\
\hline Employed & $54(29.7 \%)$ & $53(36.6 \%)$ & $0.194^{\dagger}$ \\
\hline Unemployed & $128(70.3 \%)$ & $92(63.4 \%)$ & \\
\hline \multicolumn{4}{|l|}{ Educational status } \\
\hline Primary school & $82(45.1 \%)$ & $76(52.4 \%)$ & $0.398^{\ddagger}$ \\
\hline High school & $56(30.8 \%)$ & $37(25.5 \%)$ & \\
\hline College & $44(24.2 \%)$ & $32(22.1 \%)$ & \\
\hline \multicolumn{4}{|l|}{ Cigarette smoking } \\
\hline Yes & $49(26.9 \%)$ & $43(29.7 \%)$ & $0.621^{\dagger}$ \\
\hline
\end{tabular}

${ }^{\star} t$ : test; ${ }^{\dagger}$ Fisher's exact test; ${ }^{\dagger} \chi^{2}$ test.

The prevalence of bruxism was found to be $29.7 \%(n=54)$ in the patient group, but only $12.4 \%(\mathrm{n}=18)$ among the controls, and the difference was statistically significant $(\mathrm{p}<0.001)$.

Although nocturnal bruxism occurred in 34 (63.3\%) MS patients and diurnal bruxism in only four (7.4\%) patients, bruxism occurred in $16(29.6 \%)$ patients as both diurnal and nocturnal types. The initial onset in those diagnosed with bruxism started in 38 (70.4\%) patients after the diagnosis of MS and in 16 (29.6\%) patients before the diagnosis of MS.

Compared with MS patients without bruxism, the mean age $(p=0.031)$ and EDSS score $(p=0.001)$ were found to be significantly higher in MS patients with bruxism.

No significant differences were observed between MS patients with, and without, bruxism in terms of sex, marital status, educational status, employment, cigarette smoking, disease duration, total number of MS exacerbations, number of MS exacerbations in the previous year and drugs used (Table 2).

\section{DISCUSSION}

Although the etiology of bruxism has yet to be fully understood, the formation and pathogenesis of bruxism are considered to be multifactorial ${ }^{8}$. The etiological factors are primarily grouped under two headings as morphological and central. While morphological factors include local/dental constituents, central factors are evaluated in two subgroups as pathophysiological-neurophysiological and psychological factors ${ }^{9,10}$. Although the mechanism of pathophysiologic effects on bruxism cannot be fully understood as central factors, it is a known fact that sleep bruxism is influenced by the central and autonomic nervous system involving functions of the jaw and the sleep-related center ${ }^{11}$. However, which of these factors dominates is still controversial'. Pathophysiological factors, such as cigarette smoking, various diseases, trauma, genetics, alcohol absorption, use of caffeine and illegal drugs and various treatment modalities, are involved in the etiology of bruxism ${ }^{12}$. The final diagnosis of bruxism is performed with polysomnographic methods or outpatient recording systems using electrophysiological devices ${ }^{13}$; however, the condition is often diagnosed using the diagnostic criteria of bruxism and physical examination in clinical practice. In our study, no polysomnographic methods were used to diagnose bruxism, and this may be considered a limitation. However, although polysomnography is a reliable method, it is reported that this is effective only during the active stage of bruxism, so the diagnosis via polysomnography may be faulty when the condition is inactive ${ }^{14}$.

In the present study, we determined the prevalence of bruxism in MS patients. While the prevalence of bruxism was found to be $29.7 \%$ in the patient group, the rate was $12.4 \%$ among the controls, and the difference was statistically significant. The existence of bruxism was the nocturnal type in $63.3 \%$ of the patients. On the question of the onset of the condition, we found bruxism started in $70.4 \%$ of the patients after the diagnosis of MS. This finding demonstrates that a significant association may exist between MS and bruxism. 
Table 2. Demographic and clinical data of multiple sclerosis patients with and without bruxism.

\begin{tabular}{|c|c|c|c|}
\hline Variable & Bruxism $(+)(n=54)$ & Bruxism (-) $(n=128)$ & $p$-value \\
\hline \multirow[t]{3}{*}{ Age } & $38.50 \pm 7.33$ & $35.69 \pm 9.23$ & $0.031^{*}$ \\
\hline & Range: 22-55 & Range: 19-61 & \\
\hline & Median: 39 & Median:39 & \\
\hline \multicolumn{4}{|l|}{ Sex } \\
\hline Male & $12(23.1 \%)$ & $40(76.9 \%)$ & $0.281^{\dagger}$ \\
\hline Female & $42(32.3 \%)$ & $88(67.7 \%)$ & \\
\hline \multicolumn{4}{|l|}{ Marital status } \\
\hline Married & $45(83.3 \%)$ & $98(76.6 \%)$ & $0.268^{\ddagger}$ \\
\hline Unmarried & $6(11.1 \%)$ & $26(20.3 \%)$ & \\
\hline Divorced & $3(5.6 \%)$ & $4(3.1 \%)$ & \\
\hline \multicolumn{4}{|l|}{ Employment } \\
\hline Employed & $12(22.2 \%)$ & $42(32.8 \%)$ & $0.213^{+}$ \\
\hline Unemployed & $42(77.8 \%)$ & $86(67.2 \%)$ & \\
\hline \multicolumn{4}{|l|}{ Educational status } \\
\hline Primary school & $30(55.6 \%)$ & $52(40.6 \%)$ & $0.175^{\ddagger}$ \\
\hline High school & $14(25.9 \%)$ & $42(32.8 \%)$ & \\
\hline College & $10(18.5 \%)$ & $34(26.6 \%)$ & \\
\hline \multicolumn{4}{|l|}{ Cigarette smoking } \\
\hline Yes & $18(33.3 \%)$ & $31(24.2 \%)$ & $0.207^{\dagger}$ \\
\hline No & $36(66.7 \%)$ & $97(75.8 \%)$ & \\
\hline \multicolumn{4}{|l|}{ Total number of MS exacerbations } \\
\hline $1-5$ exacerbations & $39(72.2 \%)$ & $105(82.0 \%)$ & $0.297^{\ddagger}$ \\
\hline $6-10$ exacerbations & $29(15.9 \%)$ & $17(13.3 \%)$ & \\
\hline$>10$ exacerbations & $9(4.9 \%)$ & $6(4.7 \%)$ & \\
\hline Disease duration & $7.59 \pm 5.10$ & $6.18 \pm 4.68$ & $0.069^{* *}$ \\
\hline $\begin{array}{l}\text { Number of MS exacerbations within the } \\
\text { previous year }\end{array}$ & $0.57 \pm 0.71$ & $0.58 \pm 0.66$ & $0.823^{* *}$ \\
\hline \multirow[t]{3}{*}{ EDSS } & $1.67 \pm 0.94$ & $1.21 \pm 1.13$ & $0.001^{* *}$ \\
\hline & Range: 0 - 4 & Range: $0-4.5$ & \\
\hline & Median: 2.5 & Median: 2.5 & \\
\hline \multicolumn{4}{|l|}{ Treatment regime used } \\
\hline Interferon b-1a (1/week) & $1(11.1 \%)$ & $8(88.9 \%)$ & $0.284^{\dagger}$ \\
\hline Interferon b-1a (3/week) & $12(26.7 \%)$ & $33(73.3 \%)$ & $0.708^{+}$ \\
\hline Interferon $b-1 b$ & $8(38.1 \%)$ & $13(61.9 \%)$ & $0.446^{+}$ \\
\hline Glatiramer acetate & $14(33.3 \%)$ & $28(66.7 \%)$ & $0.567^{\dagger}$ \\
\hline Teriflunomide & $2(20 \%)$ & $8(80 \%)$ & $0.726^{+}$ \\
\hline Fingolimod & $15(29.4 \%)$ & $36(70.6 \%)$ & $1.000^{+}$ \\
\hline Azathioprine & $2(50 \%)$ & $2(50 \%)$ & $0.583^{+}$ \\
\hline
\end{tabular}

EDSS: Expanded disability status scale; ${ }^{*} t$ : test; ${ }^{\dagger}$ Fisher exact test; ${ }^{\dagger} \chi^{2}$ test; ${ }^{*}$ Mann-Whitney $U$ test.

In our patients diagnosed with bruxism, a statistically significant association was found between age and bruxism. Although no significant relationship was observed between the existence of bruxism and sex, marital status, educational status, employment, cigarette smoking, medical treatment, total number of exacerbations and number of exacerbations within the previous year, a significant association was found between bruxism and the EDSS scores. This showed that, as EDSS scores increase in the patients with MS, the prevalence of bruxism may also increase. Pharmacological 
evidence has indicated that the imbalance between dopaminergic and serotonergic systems was an important entity in the etiology of bruxism ${ }^{15}$. Patients using drugs affecting dopaminergic or serotonergic systems were not included in our study. There have also been studies demonstrating that bruxism was twice as common among smokers through the increasing effect of nicotine on dopaminergic activity ${ }^{16}$. However, no association was detected between cigarette smoking and bruxism in our study.

Based on the literature, the number of studies investigating the coexistence of MS and bruxism is limited. In a recent study including a small sample population, researchers reported that temporal bone displacement was observed to be greater in MS patients than those in the control group, and the authors asserted that episodic attacks of bruxism were associated with the increases seen in intracranial pressure triggering demyelination in MS patients ${ }^{17}$. In their study, Sevim et al. ${ }^{18}$ reported on three patients with moderate-to-severe bruxism occurring within two weeks after MS exacerbations. These patients had not previously been diagnosed with bruxism, suggesting that this condition could be due to the cortico-basal ganglia-thalamocortical pathways affected in some MS episodes, possibly leading to movement disorders, such as bruxism. Sevim et al. ${ }^{18}$ also emphasized that damage or biochemical changes that occurred in the white matter with normal appearance, in a way that affected the pathways connecting the prefrontal and premotor cortices to the basal ganglia, may trigger bruxism episodes. In the present study, we did not clinically investigate the localization of MS lesions in the patients diagnosed with bruxism, and this may be considered a limitation of our study. However, it is difficult to determine the localization of the lesions and to assess their association with bruxism in diseases, such as MS, which can occur in multiple localizations.

Patients with bipolar, psychotic and anxiety disorders, or diagnosed with depression, were not included in this study. In addition, no other diagnoses were investigated in the patients using any anxiety, depression or insomnia scales, and this may be considered one of the limitations in our study.

Our study demonstrated that bruxism may be encountered more often in patients with MS, compared with the normal population, and may be associated with the patients' age level and EDSS scores. In order to detect bruxism, specialized neurologists and general neurology practitioners interested in MS should be more alert in taking the MS patient's history. This way, bruxism may be diagnosed at an early stage, and the complications from bruxism may be avoided.

\section{ACKNOWLEDGMENT}

Authors thank Numan Duran for language editing.

\section{References}

1. Thorpy MJ. Classification of sleep disorders. Neurotherapeutics. 2012 Oct;9(4):687-701. https://doi.org/10.1007/s13311-012-0145-6

2. Lavigne GJ, Khoury S, Abe S, Yamaguchi T, Raphael K. Bruxism physiology and pathology: an overview for clinicians. J Oral Rehabil. 2008 Jul;35(7):476-94. https://doi.org/10.1111/j.1365-2842.2008.01881.x

3. Uca AU, Uğuz F, Kozak HH, Gümüș H, Aksoy F, Seyithanoğlu A, et al. Antidepressant-Induced Sleep Bruxism: Prevalence, Incidence, and Related Factors. Clin Neuropharmacol. 2015 Nov-Dec;38(6):227-30. https://doi.org/10.1097/WNF.0000000000000108

4. Winocur E, Gavish A, Voikovitch M, Emodi-Perlman A, Eli I. Drugs and bruxism: a critical review. J Orofac Pain. 2003;17(2):99-111.

5. Glaros AG. Incidence of diurnal and nocturnal bruxism. J Prosthet Dent. 1981 May;45(5):545-9. https://doi.org/10.1016/0022-3913(81)90044-5

6. Serra-Negra JM, Scarpelli AC, Tirsa-Costa D, Guimarães FH, Pordeus IA, Paiva SM. Sleep bruxism, awake bruxism and sleep quality among Brazilian dental students: a cross-sectional study. Braz Dent J. 2014;25(3):241-7. https://doi.org/10.1590/0103-6440201302429P

7. Hoz-Aizpurua JL, Díaz-Alonso E, LaTouche-Arbizu R, MesaJiménez J. Sleep bruxism. Conceptual review and update. Med Oral Patol Oral Cir Bucal. 2011 Mar;16(2):e231-8. https://doi.org/10.4317/medoral.16.e231

8. Șener S, Karabekiroğlu S, Ünlü N. Assessment of bruxism awareness and related various factors in young adults. Cumhuriyet Dental Journal. 2014;17(4):361-71.
9. Okeson JP. Management of temporomandibular disorders and occlusion. 5th ed. USA: Mosby; 2006.

10. Bulut AC, Atsü S. Bruksizm Tanı ve Tedavisinde Güncel Yaklașımlar. KÜ Tıp Fak Derg. 2012;14(1):20-5.

11. Lobbezoo F, Naeije M. Bruxism is mainly regulated centrally, not peripherally.J Oral Rehabil. 2001 Dec;28(12):1085-91. https://doi.org/10.1046/j.1365-2842.2001.00839.x

12. Shetty S, Pitti V, Satish Babu CL, Surendra Kumar GP, Deepthi BC. Bruxism: a literature review. J Indian Prosthodont Soc. 2010 Sep;10(3):141-8. https://doi.org/10.1007/s13191-011-0041-5

13. Kryger MH, Roth T, Dement WC. Principles and practices of sleep medicine. 3rd ed. Philadelphia:WB Saunders; 2000.

14. Trindade MO, Rodriguez AG. Polysomnographic analysis of bruxism Gen Dent. 2014 Jan-Feb;62(1):56-60.

15. Ferini-Strambi L, Pozzi P, Manconi M, Zucconi M, Oldani A. Bruxism and nocturnal groaning. Arch Ital Biol. 2011 Dec;149(4):467-77.

16. Kato T, Thie NM, Montplaisir JY, Lavigne GJ. Bruxism and orofacial movements during sleep. Dent Clin North Am. 2001 Oct;45(4):657-84.

17. Williams DE, Lynch JE, Doshi V, Singh GD, Hargens AR. Bruxism and temporal bone hypermobility in patients with multiple sclerosis. Cranio. 2011 Jul;29(3):178-86. https://doi.org/10.1179/crn.2011.026

18. Sevim S, Kaleağası H, Fidancı H. Sleep bruxism possibly triggered by multiple sclerosis attacks and treated successfully with botulinum toxin: report of three cases. Mult Scler Relat Disord. 2015 Sep;4(5):403-5. https://doi.org/10.1016/j.msard.2015.06.006 